\title{
Polymorphisms of the mannose binding lectin gene in patients with Sjögren's syndrome
}

\author{
Z-Y Wang, A Morinobu, S Kanagawa, S Kumagai
}

\begin{abstract}
Objective-To investigate polymorphisms of both codon 54 allele and promoter variants of the mannose binding lectin (MBL) gene in patients with primary Sjögren's syndrome (SS).

Methods-Polymorphisms of codon 54 allele and promoter variants of the MBL gene in 104 patients with SS and 143 healthy controls were determined by polymerase chain reaction-restriction fragment length polymorphism and allele specific polymerase chain reaction respectively.

Results-The allele frequency of the wild type of MBL codon 54 was significantly higher in patients with SS than in controls $(0.836 v 0.741 ; p=0.011)$, and the frequency of the homozygous wild type of MBL codon 54 was significantly higher in patients with SS than in controls $(0.692 v$ $0.539 ; p=0.024)$. On the other hand, the allele frequencies of the MBL promoter gene did not differ between patients and controls $\left(\chi^{2}=4.01, \mathrm{df}=2, \mathrm{p}=0.135\right)$.

Conclusion-The polymorphism of the MBL gene may be one of the genetic factors that determines susceptibility to SS.
\end{abstract}

(Ann Rheum Dis 2001;60:483-486)

Sjögren's syndrome (SS) is an autoimmune exocrinopathy characterised by polyclonal B cell activation with production of autoantibodies including anti-SSA and anti-SSB autoantibodies. ${ }^{1}$ Many studies have shown genetic factors that determine susceptibility to SS, including major histocompatibility complex (MHC) genes and those outside MHC genes. $^{2-5}$ On the other hand, it has been suggested that Epstein-Barr virus and human T lymphotropic virus type I may be involved in the pathogenesis of SS. ${ }^{67}$ Moreover, similar features to those of SS have often been observed in chronic viral infections, such as those caused by HIV and hepatitis $C$ virus $(\mathrm{HCV}) .^{89}$ It could be hypothesised that putative viruses trigger the onset of SS in people with certain genetic backgrounds.

Mannose binding lectin (MBL) plays an important role in immune reactions. By binding to specific carbohydrate structures on various microorganisms, MBL facilitates phagocytosis and activates the third pathway of complement (lectin pathway) through MBL associated serine protease, as well as classical and alternative pathways. ${ }^{10-13}$ Three structural variants in the MBL gene, located separately at codons 54, 57, and 52 of exon 1, have been shown to produce variant MBL protein. ${ }^{14} 15$ Polymorphisms in the promoter region of the gene, at $-550(\mathrm{H} / \mathrm{L}$ variants $)$ and $-221(\mathrm{X} / \mathrm{Y}$ variants), result in four promoter alleles, HX, HY, LX, and LY. ${ }^{16}$ Importantly, polymorphisms in both exon 1 and the promoter region of the MBL gene have been shown to contribute to serum MBL levels. Low serum MBL levels result in impaired opsonisation and complement mediated clearance of immune complex. ${ }^{17}{ }^{18}$

Our hypothesis is that genetic polymorphisms that are involved in immune responses against viruses may influence the onset of SS. MBL seems to be one of the genetic factors responsible for persistent virus infections, because polymorphisms of the MBL gene have been reported to be associated with HIV and HCV infections, as well as childhood infections. ${ }^{19-22}$ Therefore we investigated the polymorphisms of codon 54 of exon 1 and the promoter region in the MBL gene to determine the genetic contribution of the MBL gene to SS.

\section{Methods}

PATIENTS AND CONTROLS

A total of 104 Japanese patients with primary SS were randomly selected from patients followed up at Kobe University Hospital and Kanazawa Medical School Hospital. The median age was 53.2 years (range 26-91) and the female/male ratio was $10.5: 1$. All the patients fulfilled the preliminary classification criteria proposed by Vitali et al. ${ }^{23}$ Of 78 who had had a lip biopsy, 24, 20, and 27 showed chronic sialoadenitis with a focus score of 1,2 , and $\geqslant 3$ respectively. Patients with secondary SS were excluded from the study. The control population consisted of 143 healthy Japanese subjects, including hospital staff and healthy volunteers. The median age was 43.8 years (range 22-67), and the female/male ratio was $1.1: 1$

GENOTYPING OF MBL CODON 54

DNA was extracted from peripheral blood monocytes by a standard procedure. MBL codon 54 genotypes of exon 1 were identified by PCR using primers listed in table 1 , as described previously. ${ }^{19}$ Sample DNA (500 ng) was amplified in the presence of $1.5 \mathrm{mM}$ $\mathrm{MgCl}_{2}, 0.2 \mathrm{mM}$ each $\mathrm{dNTP}$, and $2.5 \mathrm{U} / \mu \mathrm{l}$ Ampli Taq DNA polymerase (Perkin-Elmer, Norwalk, Connecticut, USA). Polymerase chain reaction (PCR) conditions, using an automated PCR thermal cycler (Gene Amp PCR system 9600; Perkin-Elmer), were as follows: an initial denaturation at $94^{\circ} \mathrm{C}$ for four 
Table 1 Primer pairs used in genotyping of mannose binding lectin

\begin{tabular}{|c|c|}
\hline Primer & Sequence \\
\hline \multicolumn{2}{|c|}{ MBL codon 54} \\
\hline Forward & 5'-GTAGGACAGAGGGCATGCTC-3' \\
\hline Reverse & 5'-CAGGCAGTTTCCTCTGGAAGG-3' \\
\hline \multicolumn{2}{|c|}{ HY promoter } \\
\hline Forward & 5'-GCTTACCCAGGCAAGCCTGTG-3' \\
\hline Reverse & 5'-GGAAGACTATAAACATGCTTTCC-3' \\
\hline \multicolumn{2}{|c|}{ LY promoter } \\
\hline Forward & 5'-GCTTACCCAGGCAAGCCTGTC-3' \\
\hline Reverse & 5'-GGAAGACTATAAACATGCTTTCC-3' \\
\hline \multicolumn{2}{|c|}{ LX promoter } \\
\hline Forward & 5'-GCTTACCCAGGCAAGCCTGTC-3' \\
\hline Reverse & 5'-GGAAGACTATAAACATGCTTTCG-3' \\
\hline
\end{tabular}

minutes; 35 cycles of denaturation at $94^{\circ} \mathrm{C}$ for 30 seconds, annealing at $58^{\circ} \mathrm{C}$ for one minute, and extension at $72^{\circ} \mathrm{C}$ for one minute; and a final elongation at $72^{\circ} \mathrm{C}$ for five minutes. The PCR products were subsequently digested with the restriction enzyme BamI (5 U; Toyobo, Ohtsu, Japan), which permits identification of the mutation through its unique cleavage site. ${ }^{14}$ The genotypes were determined by electrophoresis on $2 \%$ agarose gels stained with ethidium bromide. A fragment with the wild type allele is cleaved into two bands (245 bp and $84 \mathrm{bp}$ ), while that with the mutant allele shows one band (329 bp). Three patterns were determined as shown in fig 1A: $54 \mathrm{~W} / \mathrm{W}$ (wild/ wild), $54 \mathrm{~W} / \mathrm{m}$ (wild/mutant), and $54 \mathrm{~m} / \mathrm{m}$ (mutant/mutant).

MBL PROMOTER GENOTYPING

Genotyping of MBL promoter variants was performed by allele specific PCR. Each primer ends with an allele specific base. ${ }^{24}$ LY, LX, HY, and $\mathrm{HX}$ promoter regions were amplified using the appropriate pairs of primers in parallel reactions by PCR. Table 1 lists the sequences of primers used, and the PCRs were performed as described previously. ${ }^{24}$ The genotypes were determined by electrophoresis on $2 \%$ agarose

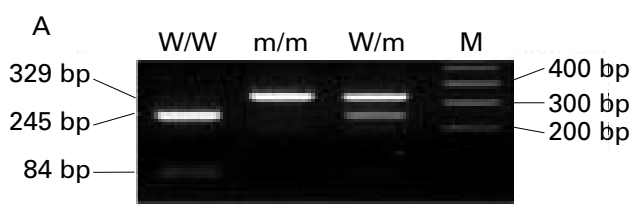

B

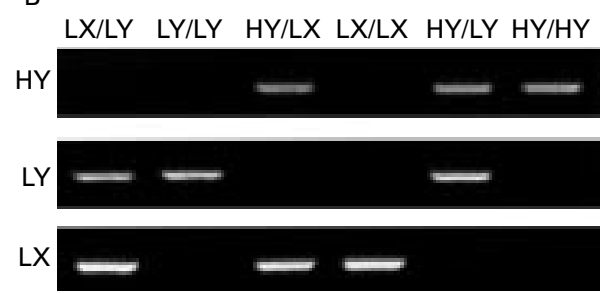

Figure 1 (A) Polymerase chain reaction

$(P C R)$-restriction fragment length polymorphism analysis for the codon 54 allele of the mannose binding lectin $(M B L)$ gene. PCR products were digested with BamI, and three genotypes of $M B L$ codon 54 were determined. $W / W$, wild/wild; W/m, wild/mutant; $m / m$, mutant/mutant; $M$, marker. (B) Allele specific PCR analysis for promoter genotypes of the MBL gene. PCR products of $H Y, L Y$, and genotypes of the MBL gene. PCR products of $H Y, L Y$,
$L X$ alleles are visualised separately by staining with ethidium bromide in $2 \%$ agarose gel, and promoter genotypes were determined according to positive bands. Representative LY/LX, LY/LY, HY/LX, LX/LX, LY/HY, and $H Y / H Y$ genotypes are shown.
Table 2 Allele and genotype frequencies of mannose binding lectin $(M B L)$ codon 54 in patients with Sjögren's syndrome and healthy control

\begin{tabular}{lrc}
\hline & Patients $(n=104)$ & Controls $(n=143)$ \\
\hline Genotypes & & \\
W/W & $72(0.692)$ & $77(0.539)$ \\
$\mathrm{W} / \mathrm{m}$ & $30(0.289)$ & $58(0.406)$ \\
$\mathrm{m} / \mathrm{m}$ & $2(0.019)$ & $8(0.056)$ \\
Alleles & & \\
$\mathrm{W}$ & $174(0.836)$ & $212(0.741)$ \\
$\mathrm{m}$ & $34(0.164)$ & $74(0.259)$ \\
\hline
\end{tabular}

The overall distribution of genotypes significantly differed between patients and controls $\left(\chi^{2}=6.69 ; \mathrm{df}=2 ; \mathrm{p}=0.035\right)$. Allele frequencies were significantly different between patients and controls (OR $1.79 ; 95 \%$ CI 1.14 to $2.80 ; p=0.011$ by Fisher's exact test).

gels stained with ethidium bromide, according to which primer pairs produced a band (fig 1B).

STATISTICAL ANALYSIS

Contingency table analyses and Fisher's exact test were used to compare the frequencies of genotypes and promoter variants between patients with SS and controls, and the allele frequencies of MBL codon 54 between positive and negative patients for clinical features. Student's $t$ test was used to compare the serum immunoglobulin levels.

\section{Results}

Table 2 shows the genotypes and allele frequencies for MBL codon 54 in the patients and controls. The overall distribution of genotypes significantly differed between patients and controls $\left(\chi^{2}=6.69 ; \mathrm{df}=2 ; \mathrm{p}=0.035\right)$. The frequency of the $54 \mathrm{~W} / \mathrm{W}$ genotype compared with $54 \mathrm{~W} / \mathrm{m}+54 \mathrm{~m} / \mathrm{m}$ was significantly higher in patients with SS than in controls (0.692 v 0.539 ; odds ratio (OR) $1.93 ; 95 \%$ confidence interval $(95 \% \mathrm{CI}) 1.14$ to $3.27 ; \mathrm{p}=0.024$ by Fisher's exact test). The allele frequency of codon 54 wild type was significantly higher in patients with SS (0.836 v 0.741; OR 1.79; $95 \%$ CI 1.14 to $2.80 ; p=0.011$ by Fisher's exact test).

Table 3 shows the genotypes and allele frequencies of the MBL promoter gene in patients with SS and controls. No HX allele was found. The allele frequencies did not deviate between patients and controls $\left(\chi^{2}=4.01 ; 2\right.$ df; $\mathrm{p}=0.135)$, although non-significant trends toward increased frequency of $\mathrm{HY}$ allele and decreased frequency of LY allele were observed $(p=0.055$ and $p=0.069$ by Fisher's exact test respectively). The frequency of the homozygous HY promoter genotype ( $\mathrm{HY} / \mathrm{HY})$ was also higher in patients with SS, but this did not reach statistical significance ( $\mathrm{p}=0.051$ by Fisher's exact test).

We did not find any correlation of MBL codon 54 genotypes with clinical features such as salivary gland swelling, gum test, lymph node swelling, and arthritis, nor with laboratory tests such as anaemia, leucocytopenia, thrombocytopenia, serum immunoglobulin levels, serum complement levels (C3, C4, and $\mathrm{CH} 50$ ), rheumatoid factor, and presence of SSA/Ro and SSB/La autoantibodies. When compared with lip biopsy findings, the frequency of focus score $\geqslant 3$ was $44.9 \%$ (22 of 49) 
Table 3 Allele and genotype frequencies of mannose binding lectin $(M B L)$ promoter variants in patients with Sjögren's syndrome and healthy controls

\begin{tabular}{lcc}
\hline & Patients $(n=104)$ & Controls $(n=143)$ \\
\hline Alleles & $106(0.510)$ & $120(0.419)$ \\
HY & $86(0.413)$ & $142(0.497)$ \\
LY & $16(0.077)$ & $24(0.084)$ \\
LX & & \\
Genotypes & $32(0.308)$ & $28(0.196)$ \\
HY/HY & $21(0.202)$ & $39(0.273)$ \\
LY/LY & $0(0)$ & $2(0.014)$ \\
LX/LX & $35(0.337)$ & $54(0.378)$ \\
HY/LY & $7(0.067)$ & $10(0.070)$ \\
HY/LX & $9(0.087)$ & $10(0.070)$ \\
LY/LX &
\end{tabular}

The allele frequency did not differ between patients and controls $\left(\chi^{2}=4.01 ; \mathrm{df}=2 ; \mathrm{p}=0.135\right)$.

in patients with SS with codon 54W/W genotype, which is higher than the $22.7 \%$ (five of 22) found in those with codon $54 \mathrm{~W} / \mathrm{m}$ or $54 \mathrm{~m} / \mathrm{m}(\mathrm{p}=0.08)$.

\section{Discussion}

Several reports have shown an association between rheumatic diseases and the polymorphisms of the MBL gene. Increased frequencies of MBL gene mutation to varying degrees have been reported in Chinese, White, and African American patients with systemic lupus erythematosus, while conflicting data for rheumatoid arthritis have been reported. ${ }^{1824-29}$ This is the first study to examine the association between MBL gene polymorphisms and susceptibility to SS.

We found that the frequency of $54 \mathrm{~W} / \mathrm{W}$ was significantly higher in patients with SS than in controls. The non-significant trend toward increased frequency of the HY promoter allele in patients with SS may be due to linkage disequilibrium with codon 54 wild type. We expected decreased frequency of the codon 54 wild type because we hypothesised that higher opportunities for infections associated with mutant codon 54 genotype may trigger the onset of SS. However, we found increased frequency of homozygous codon 54 wild type in patients with SS in this study. Both codon 54 wild type and the promoter HY allele have been shown to be associated with high serum MBL levels. ${ }^{14-16}$ Therefore it is not likely that $\mathrm{SS}$ is triggered by impaired MBL function.

There is evidence that low serum MBL levels caused by mutant genes are associated with $\mathrm{HIV}$ and HCV infections, as well as systemic lupus erythematosus. ${ }^{18212224-26}$ Under these conditions, impaired oposonisation and complement mediated clearance of immune complex caused by MBL deficiency may be involved in the disease process. ${ }^{17}{ }^{18}$ In contrast, low MBL levels may play a protective role in complement mediated tissue damage in certain inflammatory situations. For example, MBL has been observed to promote the uptake of herpes virus, and high serum MBL levels have been reported to be associated with leprosy in Ethiopians. ${ }^{30} 31$ Therefore MBL gene polymorphisms may play different roles in different diseases. These observations raise the possibility that wild type MBL may facilitate the tissue damage in inflammatory processes in the pathogenesis of SS. Measurements of serum
MBL levels in patients with SS will be useful for elucidating the role of $\mathrm{MBL}$ in the pathophysiology of SS.

The interracial differences of MBL gene polymorphisms are well known. The codon 54 mutation has been found in caucasians, Asians, and Eskimos, and the codon 57 mutation is almost exclusively present in Africans, while the codon 52 mutation has been reported in both Africans and Caucasians. ${ }^{14} 15$ We studied polymorphism of the codon 54 allele, because it has been reported that mutant genotypes of codon 57 and 52 are not present in Japanese subjects. ${ }^{22}$ The allele frequency of wild type codon 54 of the MBL gene was 0.741 in this study, which is consistent with the results of a previous study of the Japanese population. ${ }^{22}$ Studies in different ethnic groups are useful for assessing the contribution of the MBL allele to susceptibility to SS, because, like HLA class II and complement genes, the importance of codon 54 wild type may differ among ethnic groups.

Because the causes of SS are heterogeneous, the contribution of the MBL gene should be considered in combination with other genetic and environmental factors. We have previously reported that TAP2 ${ }^{\star} \mathrm{Bky} 2$ and GSTM1 null genotypes are found in Japanese patients with SS (OR 1.72 and 2.36 respectively). ${ }^{4}$ In this report, we have shown the increased frequency of wild type codon 54 of the MBL gene in patients with SS. We believe that polymorphism of the MBL gene is one of the genetic factors for SS susceptibility. Further studies are required to confirm the contribution of $\mathrm{MBL}$ to the pathogenesis of SS.

The work is in part supported by a Grant-in Aid for Scientific Research (11670446) from the Japan Society for the Promotion of Science. The authors are grateful to Dr Susumu Sugai (Kanazawa Medical School, Ishikawa, Japan) for kindly providing the patient samples.

1 Moutsopoulos HM. Sjögren's syndrome. In: Klippel JH, ed. Primer on the rheumatic diseases. 11th ed. Atlanta: Arthritis Foundation, 1997:283-8.

2 Wilson RW, Provost TT, Bias WB, Alexander EL, Edlow DW, Hochberg MC, et al. Sjögren's syndrome: influence of multiple HLA-D region alloantigens on clinical and serologic expression. Arthritis Rheum 1984;27:1245-53.

3 Harley JB, Alexander EL, Bias WB, Fox OF, Provost TT, Reichlin M, et al. Anti-Ro (SS-A) and anti-La (SS-B) in patients with Sjögren's syndrome. Arthritis Rheum 1986; 29:196-206.

4 Kumagai S, Kanagawa S, Morinobu A, Takada M, Nakamura K, Sugai S, et al. Association of a new allele of the TAP2 gene, TAP2`Bky2 (Val577), with susceptibility of Sjögren's syndrome. Arthritis Rheum 1997;40:1685-92.

5 Morinobu A, Kanagawa S, Koshiba M, Sugai S, Kumagai S. Association of the glutathione S-transferase M1 homozygous null genotype with susceptibility to Sjögren's syndrome in Japanese individuals. Arthritis Rheum 1999; 42:2612-5.

6 Saito I, Servenius B, Compton T, Fox RI. Detection of Epstein-Barr virus DNA by polymerase chain reaction in blood and tissue biopsies from patients with Sjögren's syndrome. J Exp Med 1989;169:2191-8.

7 Mariette X, Agbalika F, Daniel MT, Bisson M, Lagrange P. Brouet JC, et al. Detection of human T lymphotropic virus type I tax gene in salivary gland epithelium from two patients with Sjögren's syndrome. Arthritis Rheum 1993; 36:1423-8.

8 Itescu S, Brancato LJ, Buxbaum J, Gregersen PK, Rizk CC, Croxson TS, et al. A diffuse infiltrative CD8 lymphocytosis syndrome in human immunodeficiency virus (HIV) infection: a host immune response associated with HLA-DR5. Ann Intern Med 1990;112:3-10.

9 Pawlotsky JM, Roudot-Thoraval F, Simmonds P, Mellor J, Yahia MB, André C, et al. Extra-hepatic manifestations in chronic hepatitis $\mathrm{C}$ and hepatitis serotypes. Ann Interm Med 1995;122:169-73.

10 Kuhlman M, Joiner K, Ezekowiz RA. The human mannosebinding protein functions as an opsonin. J Exp Med 1989; 169:1733-45. 
11 Matsushita M, Fujita T. Activation of the classical complement pathway by mannose-binding protein in association with a novel

12 Lu JH, Thiel S, Wiedmann H, Timpl R, Reid KB. Binding of the pentamer/hexamer forms of mannan-binding protein to zymosan activates the proenzyme $\mathrm{C} 1 \mathrm{r} 2 \mathrm{C} 1 \mathrm{~s} 2$ complex of the classical pathway of complement without involvement of C1q. J Immunol 1990;144:2287-94.

13 Thiel S, Jensen TV, Stover CM, Schwaeble W, Laursen SB, Poulsen K, et al. A second serine protease associated with mannan-binding lectin that activates complement. Nature 1997;386:506-10.

14 Lipscombe RJ, Sumiya M, Hill AVS, Lau YL, Levinsky RJ, Summerfield JA, et al. High frequencies in African and non-African populations of independent mutations in the mannose binding protein gene. Hum Mol Gen 1992;1: mannose

15 Madsen HO, Garred P, Kurtzhals JAL, Lamm LU, Ryder LP, Thiel S, et al. A new frequent allele is the missing link in the structural polymorphism of the human mannanin the structural polymorphism of the human mar
binding protein. Immunogenetics 1994;40:37-44.

16 Madsen HO, Garred P, Thiel S, Kurtzhals JAL, Lamm LU, Ryder LP, et al. Interplay between promoter and structural gene variants control basal serum level of mannan-binding protein. J Immunol 1995;155:3013-20.

17 Super M, Thiel S, Lu J, Levinsky RJ, Turner MW. Association of low levels of mannan-binding protein with a common defect in opsonisation. Lancet 1989;2:1236-9.

18 Lau YL, Lau CS, Chan SY, Karlberg J, Turner MW. Mannose-binding protein in Chinese patients with systemic lupus erythematosus. Arthritis Rheum 1996;39:706-8.

19 Sumiya $M$, Super M, Tabona P, Levinsky RJ, Arai T, Turmer MW, et al. Molecular basis of opsonic defect in immunodeficient children. Lancet 1991;337:1569-70.

20 Summerfield JA, Sumiya M, Levin M, Turner MW Association of mutations in mannose binding protein gene with childhood infection in consecutive hospital series. with childhood infection

21 Garred P, Madsen HO, Balslev U, Hofmann B, Pedersen C, Gerstoft J, et al. Susceptibility to HIV infection and
progression of AIDS in relation to variant alleles of mannose-binding lectin. Lancet 1997;349:236-40.
22 Matsushita M, Hijikata M, Ohta Y, Iwata K, Matsumoto M, Nakao K, et al. Hepatitis C virus infection and mutations of mannose-binding lectin gene MBL. Arch Virol 1998;143: 645-51.

23 Vitali C, Bombardieri S, Moutsopoulos HM, Balestrieri G, Bencivelli W, Bernstein RM, et al. Preliminary criteria for the classification of Sjögren's syndrome: results of a prospective concerted action supported by the European community. Arthritis Rheum 1993;36:340-7.

24 Sullivan K, Wooten C, Goldman D, Petri M. Mannosebinding protein genetic polymorphisms in Black patients with systemic lupus erythematosus. Arthritis Rheum 1996; 39:2046-51.

25 Garred P, Madsen HO, Halberg P, Petersen J, Kronborg G, Svejgaard A, et al. Mannose-binding lectin polymorphisms and susceptibility to infection in systemic lupus erythematosus. Arthritis Rheum 1999;42:2145-52.

26 Ip WK, Chen SY, Lau CS, Lau YL. Association of systemic lupus erythematosus with promoter polymorphisms of the mannose-binding lectin gene. Arthritis Rheum 1998;41: 1663-8.

27 Davies EJ, Snowden N, Hillarby MC, Carthy D, Gremnan $\mathrm{DM}$, Thomson W, et al. Mannose-bindng protein gene polymorphism in systemic lupus erythematosus. Arthritis polymorphism in system

28 Stanworth SJ, Donn RP, Hassall A, Dawes P, Ollier W, Snowden N. Absence of an association between mannosebinding lectin polymorphism and rheumatoid arthritis. $\mathrm{Br} \mathrm{J}$ Rheumatol 1998;37:186-8.

29 Graudal NA, Homann C, Madsen HO, Svejgaard A, Jurik AG, Graudal HK, et al. Mannan binding lectin in rheumatoid arthritis. A longitudinal study. J Rheumatol 1998;25: 629-35

30 Fischer PB, Eriksen SE, Thiel S, Jensenius JC, Mogensen SC. Mannan-binding protein and bovine conglutinin mediate enhancement of herpes simplex virus type 2 infection in mice. Scand J Immunol 1994;39:439-45.

31 Garred P, Harboe M, Oettinger T, Koch C, Svejgaard A. Dual role of mannan-binding protein in infections: another case of heterosis? Eur J Immunogenet 1994;21:125-31. 